\title{
The Constitutional Court Decision on Societal Organization Law and Its Implication toward Freedom of Association of Traditional Beliefs Community in Indonesia
}

\author{
Andy Omara ${ }^{1}$, Kristina Viri ${ }^{2}$ \\ ${ }^{1.2}$ Universitas Gadjah Mada \\ Yogyakarta, Indonesia \\ andy.omara@mail.ugm.ac.id
}

\begin{abstract}
In the past, freedom of association of the indigenous community in performing their traditional believes was not adequately protected. However, two constitutional court decisions in 2013 and 2016 provide significant protections for indigenous community in exercising such freedom. Unfortunately, there are some regulations which contrary to these two Constitutional Court rulings. This paper aims to discuss: (1) the journey of the indigenous religion group in exercising freedom of association. (2) two constitutional court decision in 2013 and 2016 and their implication to freedom of association for indigenous religion group. This paper concludes that: 1) In the past, indigenous community often experienced violence and coercion when exercising their right of association. However, 2) Two constitutional court decision strengthen their right to associate. The Court ruled that registration is not mandatory to establish a societal organization. The Court decisions should be taken into account by the regulation makers. Unfortunately, some local parliaments failed to acknowledge the existence of the Court decisions. As a result, they still require registration to establish societal organization in the regions.
\end{abstract}

Keywords- Freedom of Association, Traditional Beliefs Community, Constitutional Court in Indonesia.

\section{INTRODUCTION}

Freedom of association is guaranteed under the 1945 Indonesian Constitution 1945.[1] This constitutional guarantee is then confirmed by the 2013 Constitutional Court Decision on Societal Organization.[2] The Court ruled that registration of societal organization is voluntary. Registration is necessary only for an organization which aims to access state financial assistance. Nonregistered societal organization cannot be the basis of the government to declare that a societal organization is forbidden or illegal organization.

In some regions, however, there are regional regulations which require societal organizations to be registered in Ministry of Home Affair. [3] In case they do not register their organization, they will not be able to access government facilities including budget, room, and data. This regulation is applicable to any societal organizations including religious organization of indigenous community. For traditional community, if they fail to register their religious organization, they will not be able to obtain identity cards (the KTP) which is very important for every Indonesian citizen to access government facilities. In the ID card, it mentions "Belief in God" in the belief column.

In addition, there are other regulations including Circular Letter of the Director General Population and Civil Registration Ministry of Home Affairs Number 471.14/10666/DUKCAPIL, which obligate indigenous community register their organization. These two letters stated that it is compulsory for indigenous community to fill their organization if they intend to complete their ID card with their religious identity. [4]

In Indonesia, freedom of association toward indigenous people is a dynamic issue.[5] In 1965, after the national tragedy of G30S/PKI, some indigenous community organizations were disbanded by government.[6] Some of them were forced to choose one of five religions official religions recognized by the Government. The incident caused trauma in some indigenous religion groups. One example is Sunda Wiwitan community in Cigugur, Kuningan, West Java. Sunda Wiwitan was dissolved by the government due to Population Administration and Civil Registration regulation which required citizens to choose one of the recognized religions. [7]

After reformation in 1998, regulations obligate indigenous religion group register their organization under Ministry of Education and Culture or Ministry of Home Affair remains the same. However, some indigenous community did not want to register their organization. As a result, they cannot access their constitutional rights such as education, health, and civil administration document. They are also seen as atheist.

There are two constitutional court decisions which somewhat change this situation: the Constitutional Court Decision Number 97/PUU-XIV/2016 (the 2016 Court decisions) and the Constitutional Court Decision number 82/PUU-XI/2013 (the 2013 Court decision). These two Court decisions provide constitutional protection and 
guarantee toward traditional community fundamental rights. The 2016 Court decision ruled the status of people with indigenous religion can be included in the family registration certificates (the KK) and identity card ( the KTP) without specifying the beliefs they are embraced. .[8] The 2013 Court decision declared the registration of societal organization is mandatory including indigenous beliefs as mentioned in Law $17 / 2013$ on Societal Organization. The implementation of societal organization Law however is problematic. This paper aims to answer an important question i.e. How does the 2013 Court Ruling affect freedom of association of traditional beliefs community?

\section{RESEARCH METHOD}

This is a qualitative normative legal research. It examines whether the existing laws and regulations consistent with the Court decisions. Existing literatures show some studies in this topic: Riza Immadudin Abdali wrote Politics of Administration for the Freedom of Association of Penghayat Kepercayaan and The Implication of Access to Resources and Public Service in Indonesia. His study finds: [9] (1) Registration letter is a form of legitimacy for traditional beliefs community to be recognized by the government. (2) the obligation to register for traditional beliefs community can be seen as a confrontation between community identity and stigmatized communities. This policy increases the vulnerability of minority groups, including indigenous religion group.

In addition, Kristina Viri analyzed The Dynamics of Recognition of Indigenous Religion Group in Indonesia.[10] It analyzes the rights of Indigenous people to have religion and worship after the Constitutional Court Decision Number 97/PUU-XI/2016. This study was not analyzing the right to associate. This paper will complement the two studies mention-above by analyzing freedom of association for indigenous religion groups.

\section{FINDINGS AND DISCUSSION}

\section{Dynamics of Right to Associate for Traditional Beliefs Community in Indonesia}

To obtain comprehensive understanding on freedom of association toward traditional beliefs community, it is important to understand the history of indigenous people and its belief in Indonesian. This Part will explain indigenous people prior to 1999 reformasi and post 1999 reformasi.[11]

\section{Prior to 1999 Reformasi}

There were two important events related to the right of associations for indigenous religion group: the establishment of Coordinating Board for supervision of Community Beliefs (the BAKORPAKEM) and the 1965 national tragedy of the Indonesian Communist Party Rebellion (G30 S/PKI). a) Establishment of the BAKORPAKEM

In 1953, the governments established the BAKORPAKEM.[12] This body was established after Minister of Religion reported there were 360 new religions and believe. Groups that are not included in the definition of religion has monitored by the BAKORPAKEM. In practice indigenous religion groups are forced to choose one of the 5 (five) official religions. BAKORPAKEM apart from supervising was also authorized to carry out investigations, and even disband organizations or indigenous religion groups. This board is under the coordination of the Attorney General's Office whose members are the police, Indonesian Army, local government and the Attorney General's Office.

b) G30 S PKI and Establishment Law Number 1 PNPS 1965

The incident which commonly known as the G30 SPKI, has impacts to indigenous religion group. At that time there was a massive shift from indigenous religion choose one religion that was recognized religion. [13] It was forced by the government. If they did not choose a religion that is recognized, they are labelled as communists. As a result the Organizations may be dissolved; members and leaders may be arrested.

Establishment Law Number 1 PNPS 1965 was the interest of the Santri groups (Islamic group) who have entered the government through the Ministry of Religion. This group has prevented the formulation of new religion including Indigenous religion. The Law stipulates "there were several groups which were related with mysticism or traditional beliefs and other group which using Religion as the subject, has recently increased. There are many and have developed in a very dangerous direction for the existing religions. " [14]

From 1971 to 1983 , the Attorney General Office had banned 6 (six) sects of traditional beliefs as well as sects in official religions. They are: Darul Hadith sect, Islam Jemaah, Manunggal Indigenous Religion, Agama Budha Jawi Wisnu, Sanyoto's Javanese Religion; Jehovah's Witnesses. In addition, there were other groups who are required to change their organization name or chose one of 5 recognized organizations. Organization called Kawruh Naluri (KWN) in Central Java was one of that organizations. Some of them choose Buddhist or Christian as their religion. [15]

\section{After Reformation Era}

There are three important events related to freedom of association which will be discussed in this Part: the establishment of Law on Population and Administration, the issuance of Societal Organization Law, and Judicial Reviews related to freedom of association toward traditional community. These three events show how the government views on freedom of association is different from or event contradictory to the Court opinions.

In 2006 House of Representative established Law Number 23/2006 on Population and Administration. The law allowed traditional beliefs community obtain ID cards. However, the religion column remains blank or written as (-).. [16] For registration of marriages, 
regulations derived from this Law require the registration of indigenous or traditional belief organization. Such registration is mandatory for those in order to get access administration documents. [17]

In 2013 Societal Organization Law was enacted. This Law provides very broad definition on societal organization including indigenous group or traditional belief community. [18] Societal organization is required to register their organization in government office to exercise their rights. Some of them have to conduct double registration. First, they have to be registered in the Ministry of Education and Culture. Second, they have to be registered in the Ministry of Home Affair. [19] As a result it potentially violates the rights of traditional belief groups.

Apart from the two Court decisions mentioned above, there are two judicial reviews that have been granted by the Constitutional Court. First, judicial review of Law $17 / 2013$ on Societal Organization. In this case, the Court ruled registration of a societal organization is voluntary not mandatory. Second, judicial review Law 23/2006 on Population and Administration. The Court ruled that indigenous religion /traditional belief have access to ID card and the ID Card will recognize their traditional belief by mentioning the phrase "Kepercayaan terhadap Tuhan Yang Maha Esa (Belief in One Supreme God)" in the religion column of their ID Card.

\section{The Implication of the 2013 Court Decision and 2016 Court Decision of Freedom of Association for Traditional Beliefs Community}

The Constitutional Court was inserted in 2001 during the 3rd Constitutional Amendment. [20] Establishment of the Constitutional Court was important for two reasons. .[21] First, the making of laws and regulations was dominated by the executive and the legislature. Therefore, the introduction of Constitutional aims to check the constitutionality of laws (the product of the legislature and the executive) against the Constitution. Second, there is no review mechanism through judiciary. judicial review strengthens the adoption of checks and balances mechanism specifically toward the legislature products. The Constitutional Court ruling is final and binding. This means there is no further legal avenue to challenge the Court Decision. .[22]

The 2013 Court Decision on Societal Organization Law invalidated some of articles of the Law. The Court ruling affect: (a) Registration of societal organizations is voluntary. In other words, all societal organizations, either registered or unregistered, shall be recognized and protected. (b) Societal organizations (Ormas) membership do not based on territory. (c) The authority of ministers, governors, regents/mayors to issue Registered Certificates (SKT)-for societal organizations is abolished. (d) The government and/or local governments is prohibited to force CSOs to follow the government agendas.

The Court decision is based on Articles 28 and $28 \mathrm{E}$ paragraph 3 of the Constitution. They are the constitutional basis to cancel some articles of Societal organization Law. The Court was of the opinion that .[23] "...the lawmakers who represent the power of the state in lawmaking process should not be arbitrary..." The Court Justices further stated that based on the constitutional principle of freedom of assembly and association, a Societal Organization (Ormas) that does not register the organization to the relevant governmental agency will not receive services/facilities from the government (state). The state, however, cannot label the unregistered societal Organization as a prohibited organization. In addition to the mandatory registration, the Constitutional Court also interprets freedom of association to be associated with empowerment of societal organization by the government. The State should not interfere the enjoyment of these freedoms except within the limits permitted by the Constitution.

The fact that registration of societal organizations is voluntary is also applicable for indigenous religion group as religious organization is included in societal organization. For traditional community, the Court ruling benefits them because they do not need to register their organization anymore. Their freedom of assemble and worship is finally guaranteed by The Constitutions through the Constitutional Court decision.

Some local governments, however, interpreted clause "..does not receive service from the government" differently. They interpreted such phrases as a requirement for traditional community to access government facilities. In fact local governments should take into account the 2016 Court Ruling which mentions "The Population Administration Law aims to create an orderly population administration by establishing a national population database and the validity and correctness of published population documents. Efforts to carry out an orderly population administration as referred to in the article must not at all reduce the rights of citizens, including the right to freedom of religion and belief." It can be said that based on this Court opinion, local governments do not have the power to force indigenous religion group to register their organization.

Both the 2013 Court ruling and the 2016 Court ruling strengthen their constitutional rights and freedom of traditional communities including their traditional beliefs. The fact is some local regulations requires registration for societal organization. This raises question whether local governments may establish regulation which substantively in contrary to the norm of the Constitution. Indonesia's legislative system adopts Hans Kelsen's legislation hierarchy. [24] Laws and regulations are organized in the hierarchy. The 1945 Constitution is the highest law of the land followed by MPR decrees and statutes. [25] All laws and regulations should refer to and consistent with the higher level of laws and regulations including the Constitution as the highest law of the land. In the event they are in contradiction to higher level of laws and regulations, they may be invalided by the Court. Indonesia hierarchy of legislative system somewhat influenced by Hans Kelsen and Hans Nawiasky Theory. Hans Nawiasky developed Hans Kelsen's theory with a theory called theorie van stufenbau der rechtsordnung. 
The arrangement of norms according to the theory is as follow: [26]

a. State fundamental norms

(Staatsfundamentalnorm);

b. Basic Rules of the State (Staatsgrundgesetz);

c. Formal legislation (Formellgesetz);

d. Implementing regulations and autonomous regulations (verordnung en autonome satzung).

In addition, the Indonesia'constitutional law scholar, Hamid S. Attamimi, refer to Nawiasky's theory and adopts it to Indonesia's legislative law. For Attamimi, the hierarchy and legal system of Indonesia are as follows: .[27]

a. Staatsfundamentalnorm: Pancasila (Preamble to the 1945 Constitution)

b. Staatsgrundgesetz: The body of the 1945 Constitution, TAP MPR, and the Constitutional Convention.

c. Formellgesetz: Law.

d. Verordnung en autonome satzung: Hierarchically starting from Government Regulations to Regent/Mayor Decrees.

The Indonesian hierarchy of legislation according to Article 7 of Law 12/2011 on the Establishment of Legislations, is as follow:

a. The 1945 Constitution of the Republic Indonesia;

b. Decree of the People's Consultative Assembly;

c. Laws/Government Regulations in Lieu of Laws;

d. Government Regulations;

e. Presidential Regulation

f. Provincial Regulations;

g. Regency/City Regional Regulations.

The above-mentioned legislative system will be utilized to test whether the local regulations is constitutionally and legally valid. In addition, it is also important to locate the position of Court Decision. Where is the position of the Constitutional Court Ruling in that hierarchy? the hierarchy of legislation does not say anything about the Court ruling. However, The Court decisions specifically the 2013 and 2016 Court decisions invalidated some provision of the Laws. It means those provisions were not valid anymore because of the Court decisions. The Court decision becomes valid interpretation replacing the invalidated provisions.

In addition, the inclusion of the Court rulings in the State Gazette indicates that the Court rulings equal to the law. Laws including societal organizations law is also placed in state gazette. Based on the above explanation, it can be said that the Court decisions equals to law. Therefore, the status of the Court decision is above the regional regulations and ministerial regulations. In consequences, local regulations should refer to and consistent with the Court decisions. The fact that the local regulations is allegedly inconsistent with the Court ruling can be the legal basis to invalidate the regional regulations. Such invalidation however should be based on the review conducted by the judiciary. it is therefore crucial to submit the petition to the Supreme Court asking to tests the legality of the local government. If the Court proved that it is not in line with the Court decisions it is likely that such provisions will be declared as invalid.

\section{IV.CONCLUSION}

This paper has examined that the freedom of association of traditional believers are constitutionally guaranteed. However, some laws including Law on Administration and Law on Societal Organization limit such freedom by requiring such organizations to be registered in the government administrative institutions. These two laws were then reviewed by the Court. The Court ruled that such legal requirements are contradictory to the Constitution which guarantee freedom of association. The Court therefore invalidated some provisions of thses two laws. The Court decisions in these two cases, however, are interpreted differently by some local governments. Rather than allowing societal organization to exist without any registration, some regional regulations require such organization to be registered in the government administration office so that they can access government services. In this case, the local regulations which requires registration can be seen in contradictory to the Court rulings which declare that registration is not mandatory. Recognizing that the status of the Court rulings is higher than the regional regulations, it is likely that such regional regulation will be invalidated by the Court if it is proven that they are not in line with higher level of laws and regulations including the Court decisions. To prove the validity of such regional regulations, however, such regulations should be reviewed by the Supreme Court because only the Supreme Court has the power to review regulations beneath the law against the laws.

\section{REFERENCES}

[1] Article 28 and Article 28 E (3) of the 1945 Constitution

[2] the Constitutional Court Decision Number 82/PUU-XI/2013.

[3] Riza Imaduddin Abdali Ronal Rofinadri, Miftah Fadli, Kristina Viri , Penyusunan Instrumen Alternatif Surat Keterangan Terdaftar, Jakarta: YAPPIKA, 2018.

[4] Riza Immadudin, Ronal Rofinadri, Miftah Fadli, Laporan Monitoring dan Evaluasi Implementasi Undang Undang Ormas Tahun ke-5, Jakarta: Koalisi Kebebasan Berserikat, 2018.

[5] Kristina Viri, Zarida Febriani "Dinamika Pengakuan Penghayat Kepercayaan di Indonesia”, Indonesian Journal of Religion and Society, Vol. 2, No. 2, Desember 2020

[6] Ibid

[7] Rakhmat Hidayat, "The Contesting Citizenship in Indonesia Contemporary: Comparative Study of Sunda Wiwitan Cigugur and Kampong Cireundeu" The First International Conference on Indigenous Religion, Yohyakarta: CRCS UGM, 2019.

[8] Kristina Viri, Op.Cit

[9] Riza Immaduddin, "Politics of Administration for the Freedom of Association of Penghayat Kepercayaan and The Implication of Access to Resources and Public Service in Indonesia" The First International Conference on Indigenous Religion (CRCS UGM, 2019)

[10]Freedom of Religion in Indonesia https://pshk.or.id/blogid/freedom-of-religion-in-indonesia/ 
[11]Rumadi,, Uli Parulian Sihombing, , Febi Yonesta., Trisasongko, D., A.M, F., Arianingtyas, R., \& Putra, T. A, Menggugat BAKOR PAKEM: Kajian Hukum Terhadap Pengawasan Agama Dan Kepercayaan Di Indonesia, Jakarta: The Indonesian Legal Resource Center (ILRC), 2008.

[12]Samsul Maarif, Pasang Surut Rekognisi Agama Leluhur dalam Politik Agama di Indonesia, Yogyakarta: CRCS, 2019.

[13]Kristina Viri, "Menelusuri Diskriminasi Terhadap Pemeluk Kepercayaan Kawruh Naluri/KWN Di Gombong-Kebumen, dan Desa Banjarpanepen-Banyumas", The First International Conference on Indigenous Religion, CRCS UGM, 2019.

[14]Kristina Viri, "Menelusuri Diskriminasi Terhadap Pemeluk Kepercayaan Kawruh Naluri/KWN Di Gombong-Kebumen, dan Desa Banjarpanepen-Banyumas", The First International Conference on Indigenous Religion, CRCS UGM, 2019.

[15]Bani Syarif Maula, "Religious Freedom in Indonesia: Between Upholding Constitutional Provisions and Complying with Social Considerations", Journal of Indonesian Islam, Vol 07, Number 0, December 2013

[16]Aliansi Masyarakat Adat Nusantara, The Situation of Human Rights of Indigenous Peoples in Indonesia p 5. https://www.aman.or.id/wpcontent/uploads/2016/09/INDONESIA_AMAN_AIPP_UPR_3rdCycl e.pdf

[17] Michael Edwards, "The Oxford Handbook Of Civil Society", New York:Oxford University Press, 2011.

[18]Eryanto Nugroho 'Bill on Societal Organizations and Freedom of Association in Indonesia' Paper for research fellowahip program conducted by International center for Not for Profit Law (ICNL) 2011.

[19] Moh. Mahfud MD, 'Konstitusi dan Hukum dalam Kontroversi Isu', Jakarta: Rajawali Pres,2010.

[20] The Constitutional Court Decision Number 82/PUU-XI/2013.

[21]The Constitutional Court Decision Number 97/PUU-XIv/2016.

[22] Article 7 of Law 12/ 2011 on the Establishment of Legislations, the hierarchy of laws and regulations include:

[23] Sarja, 'Negara Hukum Teori dan Praktek', Yogyakarta: Thafa Media, 2016. 